\title{
Decomposition of ground biomass of secondary forest and yield of annual crops in no tillage system ${ }^{1}$
}

\author{
Déborah Verçoza da Silva², Tadário Kamel de Oliveira ${ }^{3}$, Jorge Ferreira Kusdra ${ }^{4}$, Faelen Taís Köln ${ }^{5}$, \\ Aliny Alencar de Lima ${ }^{6}$ Karelynne Bruna Alencar da Costa \\ http://dx.doi.org/10.1590/0034-737X201562060009
}

\begin{abstract}
The objective of this work was to evaluate the dynamics of decomposition process of chopped secondary forest system, previously enriched with legumes Inga velutina Willd. and Stryphnodendron pulcherrimum (Willd.) Hochr. and the contribution of this process to the nutrient input to the cultivation of corn and bean under no-tillage. The experimental design was a randomized block, split plot with four replications. The plots were two species (I. velutina and $S$. pulcherrimum) and the subplots were seven times of evaluation $(0,7,28,63,189,252,294$ days after experiment installation). There was no difference $(\mathrm{p} \geq 0.05)$ between the secondary forest systems enriched and no interaction with times for biomass waste, decomposition constant and half-life time. The waste of $S$. pulcherrimum trees had higher $(\mathrm{p}<0.05) \mathrm{C} / \mathrm{N}$ ratio than that I. velutina. However, this one was higher $(\mathrm{p}<0.05)$ in lignin content. Nevertheless, the dynamics of residue decomposition was similar. The corn yield was higher $(\mathrm{p}<0.05)$ in cultivation under I. velutina waste. Meanwhile, the beans planted after corn, shows similar $(\mathrm{p}>0.05)$ yield in both areas, regardless of the waste origin.
\end{abstract}

Key-words: Inga velutina, Stryphnodendron pulcherrimum, legume trees, corn, beans, Amazon.

\section{RESUMO}

\section{Decomposição da biomassa de capoeira triturada e produtividade de culturas anuais em plantio direto}

Objetivou-se, com este trabalho, avaliar a dinâmica do processo de decomposição de resíduos de capoeiras trituradas, anteriormente melhoradas com as leguminosas ingá peluda (Inga velutina Willd.) e baginha (Stryphnodendron pulcherrimum (Willd.) Hochr.) e sua influência na produtividade do milho e do feijoeiro, cultivados sequencialmente em plantio direto. O delineamento experimental foi em blocos casualizados, em parcelas subdivididas, no tempo, com quatro repetições, sendo as parcelas duas leguminosas (ingá peluda e baginha) e as subparcelas sete datas de avaliação $(0,7,28,63,189,252,294$ dias após a implantação do experimento). Não foi verificada diferença $(p \geq 0,05)$ entre as capoeiras melhoradas nem efeito da interação destas com as épocas de avaliação sobre os resíduos da biomassa, constante de decomposição e tempo de meia-vida. Os resíduos da capoeira melhorada com baginha apresentaram maior $(\mathrm{p}<0,05)$ relação $\mathrm{C} / \mathrm{N}$ do que os de ingá peluda, sendo estes últimos superiores $(\mathrm{p}<0,05)$ quanto ao teor de lignina. Porém, a dinâmica da decomposição dos resíduos foi similar para as

\footnotetext{
Submitted on: 02/12/2014 and approved em: 10/02/2015

${ }^{2}$ Universidade Federal de Acre, Centro de Ciências Biológicas, Rio Branco, Acre, Brazil. deborah.vercoza@gmail.com

${ }^{3}$ Embrapa Acre, Rio Branco, Acre, Brasil. tadario.oliveira@embrapa.br

${ }^{4}$ Universidade Federal de Acre, Centro de Ciências Biológicas e Naturais, Rio Branco, Acre, Brazil. kusdra@globo.com

${ }^{5}$ Universidade Federal de Acre, Centro de Ciências Biológicas e Naturais, Rio Branco, Acre, Brazil. fkolln@ gmail.com

${ }^{6}$ Universidade Federal de Acre, Centro de Ciências Biológicas e Naturais, Rio Branco, Acre, Brazil. linyal@gmail.com

${ }^{7}$ Universidade Federal de Acre, Centro de Ciências Biológicas e Naturais, Rio Branco, Acre, Brazil. karelynnealencar19@gmail.com

*Corresponding author: deborah.vercoza@gmail.com
}

${ }^{1}$ Este trabalho é parte da dissertação de mestrado da primeira autora. Apoio financeiro: Conselho Nacional de Desenvolvimento Científico e Tecnológico e Fundação de Tecnologia do Acre. 
duas leguminosas. A produtividade do milho foi maior $(\mathrm{p}<0,05)$ quando seu cultivo foi realizado sobre os resíduos de capoeira triturada com ingá peluda. Entretanto, o feijoeiro cultivado em sucessão ao milho apresentou a mesma $(\mathrm{p} \geq 0,05)$ produtividade em ambas as áreas, independentemente da natureza dos resíduos.

Palavras-chave: Inga velutina, Stryphnodendron pulcherrimum, leguminosas arbóreas, milho, feijão, Amazônia.

\section{INTRODUCTION}

The traditional system of agriculture in the Amazon is carried out from the clearing and burning of vegetation. Over the years, fire was used as the quickest and most economical way to clean the areas and "fertilize" the soil (Kato et al., 2003).

Studies on the slash-and-burn system showed that its main problems are nutrient losses during combustion of biomass and reducing of fallow period (Kato et al, 2006; Sampaio et al., 2008). During the vegetation burning, losses occur both of $\mathrm{C}$, in the form of $\mathrm{CO}_{2}$, and other elements, such as $\mathrm{N}$ and $\mathrm{S}$, by volatilization; and $\mathrm{P}, \mathrm{K}, \mathrm{Ca}$ and $\mathrm{Mg}$, by the movement of ash during and after burning (Dick et al, 2008; Trinity et al, 2011). As a result, the soils become depleted, by cation leaching, weeds grow and soil biota is reduced, making it impossible to use the area for agricultural purposes for several years, provoking its abandonment (Denich et al., 2005). Abandoned areas require long fallow periods for regeneration of vegetation that, through the accumulation of nutrients in their biomass, contribute to the cycling of nutrients and the partial recovery of soil fertility (Sampaio et al., 2008).

Given the advantages of no tillage farming and the need for a more sustainable agricultural production system for the Amazon region, the Embrapa Amazonia Oriental developed the no tillage farming in improved and ground secondary forest, which is a new technology to reduce the use of fire and the inclusion of the areas of secondary forest in agriculture (Kato et al., 2003). The system replaces fire to prepare the soil for secondary vegetation grinding, which will be used as coverage for cultivation in no tillage. The handling of secondary forest through the introduction of fast-growing tree species, such as legumes, contributes to restore soil fertility and also reduces fallow time (Sampaio et al., 2008). Vielhauer \& Sá (1999) observed that a secondary forest enriched with legumes, with a density of 10,000 trees $\mathrm{ha}^{-1}$, may reach in 21 months biomass production performance superior to that of a natural secondary forest of six years, being able to produce up to $49.4 \mathrm{t} \mathrm{ha}^{-1}$ of dry matter.
In the Amazon, there are various species of legumes and, among them, the Baginha (Stryphnodendron pulcherrimum) is commonly found in secondary forest areas and pastures (Andrade et al., 2012). According to Rayol et al. (2006), the Inga genus also has a high representation in natural regeneration areas of secondary vegetation.

Because of the presence of tree species, the biomass of ground secondary forest has a higher $\mathrm{C} / \mathrm{N}$ ratio and higher lignin content than that of herbaceous and shrub species (Espindola et al, 2006; Kato et al, 2006), which can influence the decomposition rate and nutrient mineralization of these residues.

The objective of this study was to evaluate the dynamics of the process of decomposition of ground secondary forest waste, previously improved with legumes Inga velutina and Stryphnodendron pulcherrimum, and its influence on corn and bean productivity, grown in succession in no tillage.

\section{MATERIAL AND METHODS}

The work was conducted in the experimental campus of Embrapa Acre, located in BR 364, km 14, toward Rio Branco, AC/Porto Velho, RO, in the geographic coordinates of $10^{\circ} 01^{\prime} 44^{\prime \prime S}$ and $67^{\circ} 41^{\prime} 09.60^{\prime \prime} \mathrm{W}$. The ecosystem of the region is tropical rainforest. The climate is equatorial, with an average annual temperature of $25{ }^{\circ} \mathrm{C}$, humidity of $80 \%$ and annual rainfall of $2,000 \mathrm{~mm}$ (Acre, 2010). In Figure 1, we observe the precipitation and temperature data from December 2011 to August 2012, collected in the weather station of Embrapa Acre, Rio Branco, AC. The area of the study, with eight years old, was composed of two types of homogeneous second forests, one with Inga velutina and one with baginha, initially sown at high density, in spaced rows of $1.0 \mathrm{~m}$ by $0.15 \mathrm{~m}$ between plants.

In October 2011, collecting of soil samples was carried out at $0-20 \mathrm{~cm}$ deep, to characterize the chemical attributes in the soil laboratory of Embrapa Acre. The soil of the experimental area is a Typical A, moderate medium/clayey texture, plain relief (Acre, 2010). The chemical characteristics of the soil before grinding the secondary forests are presented in Table 1 . 
The grinding was carried out with specific machinery, called Tritucap, in November 2011. After five days of grinding, the experiment was conducted.

The experimental design was randomized blocks in split plot, in time, with four replications, considering two types of secondary forest with eight years of age as plots, one composed of I. velutina and another of $S$. pulcherrimum. As subplots, seven evaluation periods: $0,7,28,63,189,252$ and 294 days after implantation of the experiment. The plots were $10 \mathrm{~m}$ x $10.5 \mathrm{~m}$, with side borders of $2 \mathrm{~m}$, bedside border of $1 \mathrm{~m}$.

After grinding the second forest, the mass of fresh matter was measured in the useful area of each plot and, subsequently, determined the dry matter.

To evaluate the decomposition of ground waste, we used the method of decomposition bags - litter bags (Carvalho et al., 2008). These bags were made from nylon material with dimensions of $20 \times 20 \mathrm{~cm}$, with a $1 \mathrm{~mm}$ mesh aperture. Five days after grinding of improved secondary forest, $100 \mathrm{~g}$ of the ground biomass, collected directly from the field, were placed in each litter bag, and the bags were randomly arranged in the surface of the soil in each experimental unit.

Corn (double hybrid AG 2040) was manually sown in no-tillage system, after grinding of secondary forests. The spacing was $0.9 \mathrm{~m}$ between rows, with 2-3 seeds per hole, at each $0.50 \mathrm{~m}$ in the seeding row. Base fertilization and top dressing were not done during the experiment. The experimental design was randomized blocks with two treatments (secondary forest improved with Inga velutina and baginha), being held two samples per plot, totaling to eight repetitions.

After corn harvest, the herbicides glyphosate (150 $\mathrm{mL} / 20 \mathrm{~L}^{-1}$ commercial product) and dimethyl 2,4dichlorophenoxyacetic $\left(50 \mathrm{~mL} / 20 \mathrm{~L}^{-1}\right.$ commercial product) were applied to desiccation of weeds. Subsequently, the bean was sown, from the cultivar Carioca Pitoco, spaced $0.50 \mathrm{~m}$ lines with manual sowing, 2-3 seeds per hole without basal and top dressing fertilization. The experimental design of the bean was randomized blocks with two treatments (secondary forest improved with I. velutina and baginha) and with three samples evaluated per plot, amounting to 12 repetitions.

During the bean cultivation, the insecticide carbaryl (50 ml/20L $\mathrm{L}^{-1}$ of the commercial product) was applied for controlling of corn rootworm (Cerotoma spp.).

\section{Determination of residue decomposition}

In all dates, one litter bag was collected from each plot, and the remaining mass, the constant of decomposition $(k)$ and half-life time $\left(\mathrm{t}_{1 / 2}\right)$ were evaluated at each time.

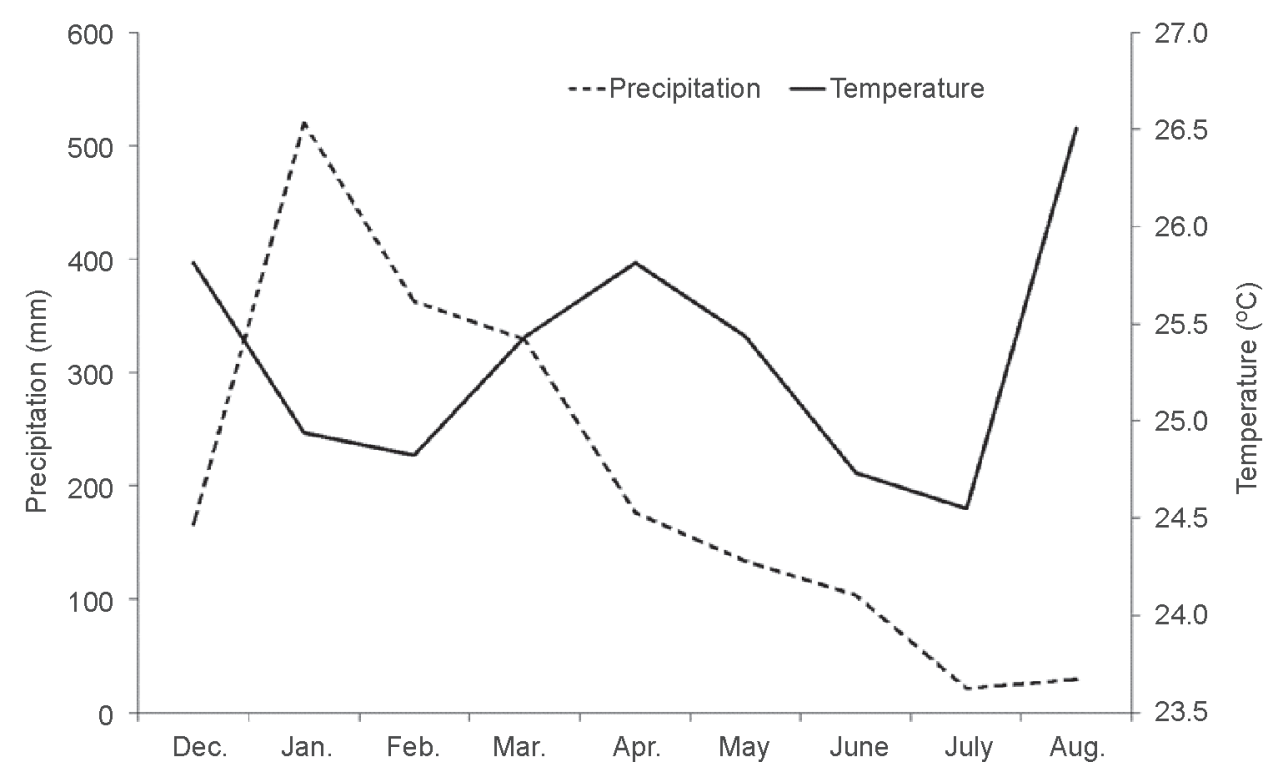

Figure 1: Rainfall (mm) and temperature $\left({ }^{\circ} \mathrm{C}\right)$ from December 2011 to August 2012, in Rio Branco, Acre. Source: Weather Station of Embrapa Acre (2013).

Table 1: Chemical analysis of soil of enriched secondary forests, at $0-20 \mathrm{~cm}$ depth before the experiment

\begin{tabular}{|c|c|c|c|c|c|c|c|c|c|c|c|}
\hline \multirow{2}{*}{$\begin{array}{l}\text { Secondary } \\
\text { Forests }\end{array}$} & \multirow{2}{*}{$\begin{array}{c}\mathbf{p H} \\
\mathrm{H}_{2} \mathrm{O}\end{array}$} & \multirow{2}{*}{$\begin{array}{l}\text { MO } \\
\mathrm{g} \mathrm{kg}^{-1}\end{array}$} & \multirow{2}{*}{$\begin{array}{c}\mathbf{P} \\
\mathrm{mg} \mathrm{dm}^{-3}\end{array}$} & $\mathbf{K}$ & $\mathrm{Ca}$ & Mg & $\mathbf{H}+\mathbf{A l}$ & Al & SB & CTC pH $_{7}$ & \multirow{2}{*}{$\begin{array}{l}\mathbf{V} \\
\%\end{array}$} \\
\hline & & & & & & & $\mathrm{cmol}_{\mathrm{c}} \mathrm{dm}^{-3}$ & & & & \\
\hline Ingá peluda & 5.05 & 2.3 & 1.25 & 0.07 & 1.6 & 0.49 & 2.3 & 0.2 & 2.16 & 4.43 & 48.8 \\
\hline Baginha & 5.22 & 6.9 & 1.47 & 0.10 & 1.8 & 0.37 & 2.2 & 0.2 & 2.26 & 4.41 & 51.2 \\
\hline
\end{tabular}


The biomass of ground waste on the soil was obtained from the measurement of the litter bag contents and verification of the corresponding dry matter for all dates.

The residue decomposition rate was evaluated according to the exponential mathematical model, described by Carvalho et al. (2008): $\mathrm{X}=\mathrm{X}_{0} \cdot \exp ^{(-k . t)}$; where $\mathrm{X}$ is the amount of dry matter, or remaining nutrient, after a period of time $t$, in days; $X_{0}$ is the amount of dry matter or initial nutrient; $\mathrm{k}$ is the decomposition constant of the waste (dimensionless).

The half-life time $\left(\mathrm{t}_{1 / 2}\right)$, which expresses the time required for half of the waste to decompose, was calculated from the expression $t_{1 / 2}=\ln 2 / k$, according to Espindola et al. (2006).

\section{Chemical composition and amount of nitrogen in the waste}

At each collection date, the material was taken out from the bags, removing possible contaminants by surface wash; dried in an oven with forced air ventilation at $65{ }^{\circ} \mathrm{C}$; the mass of each sample was measured and, subsequently, ground in a mill type Wiley, and the contents of $\mathrm{N}, \mathrm{C}$, the $\mathrm{C} / \mathrm{N}$ ratio and lignin content determined (Rodrigues, 2010).

\section{Evaluations in corn and bean crops}

In the corn harvest, the following variables were evaluated: final stand, plant height, ear index, ear diameter, ear length and productivity.

In the bean harvest, the following variables were evaluated: final stand, number of pods per plant, number of grains per pod, weight of 100 grains and productivity.

\section{Statistical analysis}

For all variables, we verified the presence of outliers by the Grubbs test, the normality of errors, by the Shapiro-Wilk test and the homogeneity of variances, by the Cochran test. The variables that required transformation to meet the assumptions of the analysis of variance were the decomposition constant $(\sqrt[3]{\mathrm{x}})$ and the $\mathrm{C} / \mathrm{N}$ ratio $(\sqrt{\mathrm{x}})$. Later, there was the analysis of variance (F test), using the Software Sisvar ${ }^{\circledR}$ (Ferreira, 2008) and the adjustment of regression equations for the variables along the evaluation periods. Some results of this work were compared with those obtained in other works by the t test.

\section{RESULTS AND DISCUSSION}

The amount of dry matter after grinding was greater $(\mathrm{p}<0.05)$ in the area with Baginha $\left(181.5 \mathrm{t} \mathrm{ha}^{-1}\right)$ than in Inga velutina (123.8 $\left.\mathrm{t} \mathrm{ha}^{-1}\right)$. Kato et al. (2003) found in a natural secondary forest of four years, a dry biomass production of $28.4 \mathrm{t} \mathrm{ha}^{-1}$. Vielhauer \& Sá (1999) in a study on spontaneous vegetation, with and without improvement with legumes, observed values of $20 \mathrm{t} \mathrm{ha}^{-1}$, in a natural secondary forest of six years old, and $49.4 \mathrm{t}$ $\mathrm{ha}^{-1}$, for an area of 21 months with legumes. Both authors have reported lower results $(\mathrm{p}<0.05)$ to those obtained in this study, probably due to the shorter fallow, and by the lower natural regeneration rate and because these studies were developed in soils with lower fertility.

In secondary forest of ten years of fallow, Kato et al. (2006) also observed result $\left(90 \mathrm{t} \mathrm{ha}^{-1}\right)$ lower $(\mathrm{p}<0.05)$ than that obtained in this work. These studies show that the high capacity of accumulation of biomass and nutrients from improved secondary forests qualify them as alternative preparation without the use of fire, after their grinding. It is worth noting that in different forest types of Acre, Salimon et al. (2011) observed values of living biomass above soil of $219 \mathrm{t} \mathrm{ha}^{-1}$ at $329 \mathrm{t} \mathrm{ha}^{-1}$.

Over time, the remaining biomass in areas with $I$. velutina and baginha were similar $(\mathrm{p} \geq 0.05)$, with a decreasing linear behavior (Figure 2). The initial average value observed was $152.7 \mathrm{tha}^{-1}$, and by the end of the study period, remained above $(\mathrm{p}<0.05)$ the minimum recommended $\left(6 \mathrm{t} \mathrm{ha}^{-1}\right)$ for ground coverage in no tillage system (Nunes et al., 2006).

The biomass enriched with legume tree species considerably exceeds the biomass produced by herbaceous and shrub cover plants in no-till fields in Brazil. Torres et al. (2005), working with shrub cover plants, obtained dry matter production between $1.6 \mathrm{t} \mathrm{ha}^{-1}$ and $10.3 \mathrm{t} \mathrm{ha}^{-1}$.

The decomposition constant $(k)$ and half-life time $\left(\mathrm{t}_{1 / 2}\right)$ (Figure 3), just as the remaining dry matter, were simi$\operatorname{lar}(\mathrm{p}>0.05)$ in secondary forests and their interactions with the evaluation times. In both areas, the decomposition process of plant waste showed a similar pattern, with accelerated initial phase, followed by a slower one. During the first 28 days, there was a weight loss of $23.1 \%$ inga) and $21.5 \%$ (baginha). However, in the last 40 days, the weight loss was only $5.0 \%$ (inga) and $5.5 \%$ (baginha). The initial value $(0.018)$ of the decomposition constant (k) indicates high decomposition rate $(>0.010)$, while at the end of the experiment, at 294 days, the waste showed higher resistance to the action of decomposing agents with decomposition rate a little above $(0.0025)$ the rate considered low (<0.0020) (Carvalho et al., 2008).

Besides the rainfall (Figure 1), the chemical composition of the waste is a fundamental element to explain the exponential model of the decomposition observed. In the first evaluation of the experiment, the high decomposition rate of waste resulted in half-life $\left(\mathrm{t}_{1 / 2}\right)$ of 40 days and, in the last, of 277 days. These results 
are due to the fact that, after the fast initial decomposition of the easily decomposable portion (soluble carbohydrates, amino acids, proteins), compounds reluctant to microbial attack remain, such as lignin and cellulose (Gamma-Rodrigues et al., (2007).

The main factor inherent to plant waste for soil coverage, which affects the decomposition rate and release of nutrients, is the $\mathrm{C} / \mathrm{N}$ ratio (Carvalho \& Guimarães Junior, 2009). In this work, there was a difference ( $\mathrm{p}<0.05)$ among secondary forests, evaluation times and the interaction between these for this variable. The baginha waste showed a C/N (129/1) ratio greater $(\mathrm{p}<0.05)$ than the I. velutina (77/1) (Figure 4). These results are considered high, close to the $\mathrm{C} / \mathrm{N}$ ratio of waste with slow decomposition rate, such as corn stover (112/1) (Calonego et al., 2012). According to Teixeira et al. (2009), materials with higher $\mathrm{C} / \mathrm{N}$ ratio (above 30 ) remain longer in the soil; however, at the beginning of decomposition, there tend to occur greater immobilization of nutrients.

The $\mathrm{C} / \mathrm{N}$ ratio of the waste in the area with Inga velutina was relatively constant, staying around 77/1, during the decomposition period evaluated. In the area with baginha, the adjusted model showed decreasing li-

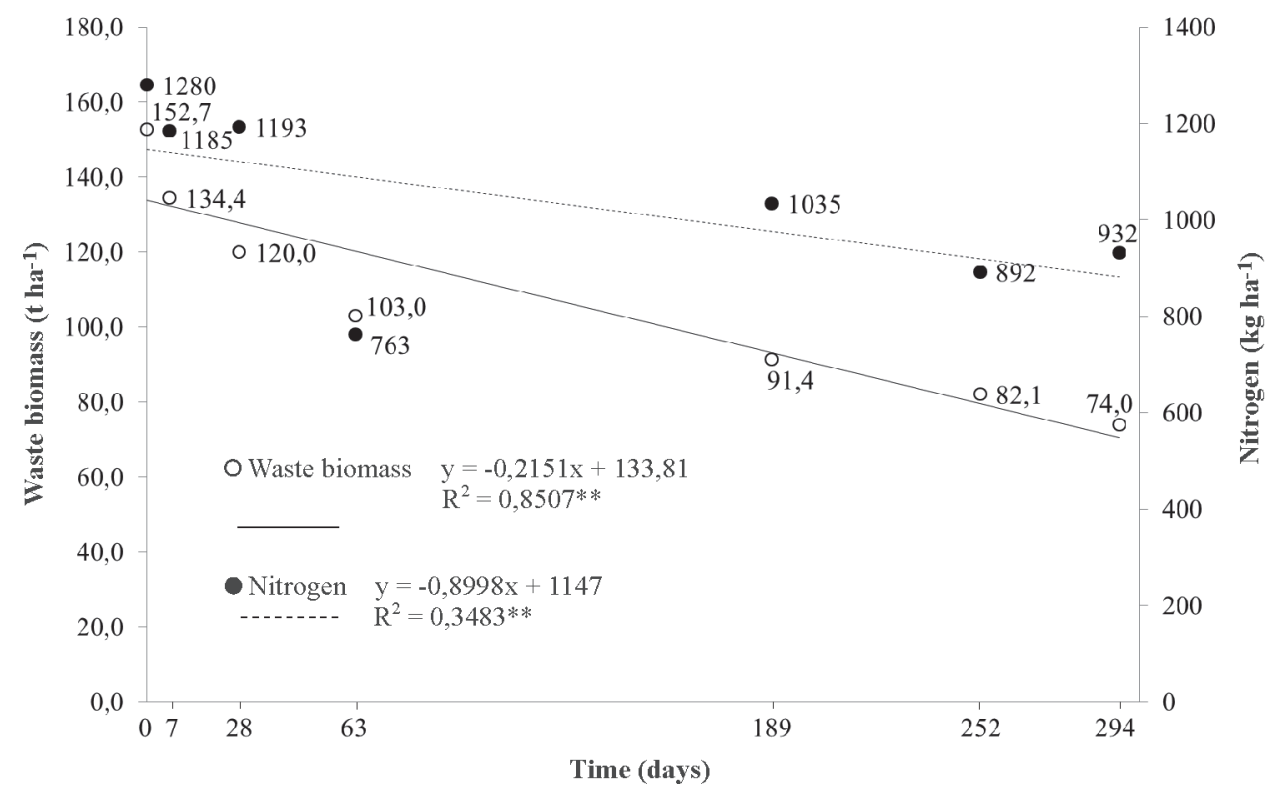

Figure 2: Waste biomass maintained in the areas and amount of $\mathrm{N}$ in the waste of legume trees, after grinding the secondary forests, in Rio Branco, Acre, 2011/2012.

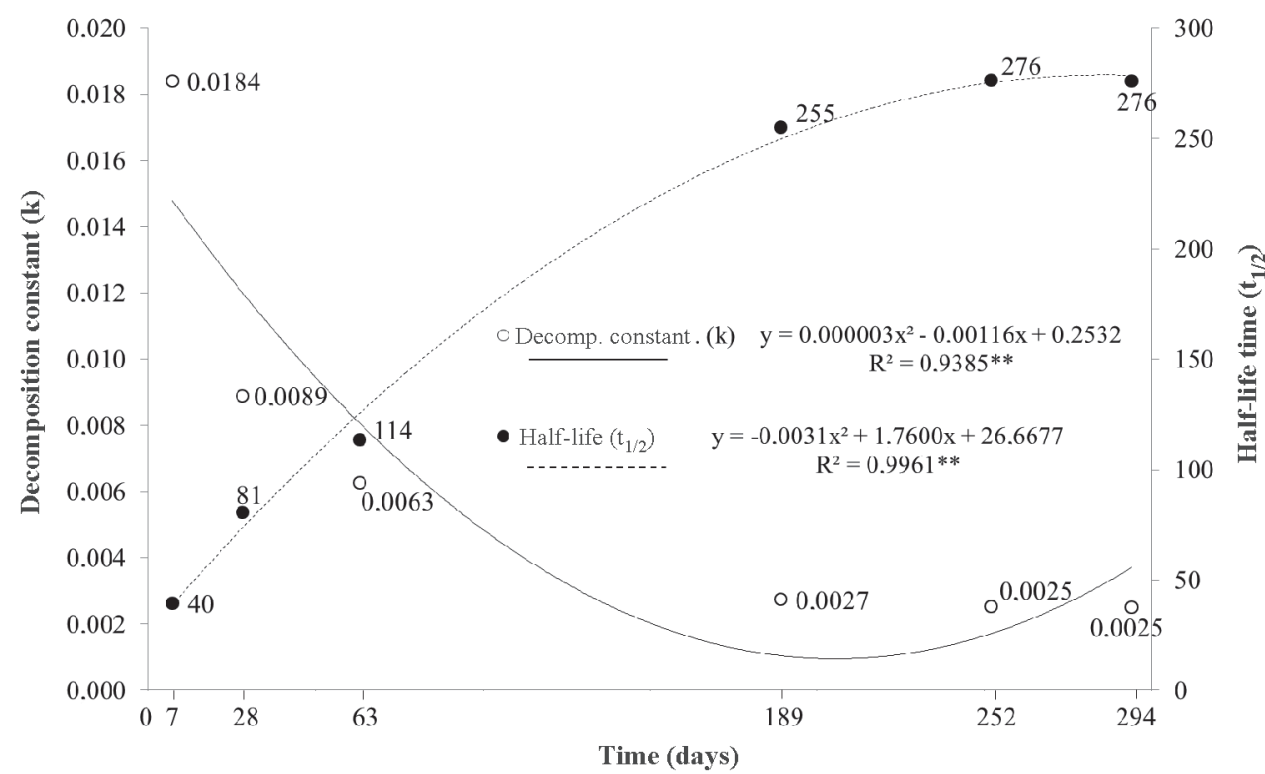

Figure 3: Decomposition constant $(\mathrm{k})$ and half-life time $\left(\mathrm{t}_{1 / 2}\right)$ of legume tree waste, after grinding the secondary forests, in Rio Branco, Acre, 2011/2012. 
near behavior. It is noted that only at 294 days the $\mathrm{C} /$ $\mathrm{N}$ ratio of baginha waste equaled the I. velutina waste ( $\mathrm{p} \geq 0.05)$ (Figure 3).

The difference in $\mathrm{C} / \mathrm{N}$ ratio of the waste of ingá and baginha was not enough to alter the decomposition rate of the species, as shown in Figure 2. This result confirms that the $\mathrm{C} / \mathrm{N}$ ratio, isolatedly, is not a reliable indication of the dynamics of the decomposition process (Carvalho et al., 2008). The ideal is the inclusion of information related to compounds of complex carbon chains, such as lignin, whose concentration in the waste of Inga velutina in this study was higher $(\mathrm{p}<0.05)$ than the baginha in all the evaluation periods (Figure 5) (Marcelo et al., 2012).

The divergent results between $\mathrm{C} / \mathrm{N}$ ratio and lignin in the biomass of baginha and Inga velutina explain the fact that these residues did not differ $(\mathrm{p} \geq 0.05)$ on the decomposition dynamics (remaining mass, $\mathrm{k}$ and $\mathrm{t}_{1 / 2}$ ), because, although the residue of Inga velutina present lower $\mathrm{C} / \mathrm{N}(77 / 1)$ ratio, its lignin content (16.9\%) was higher, comparing its decomposition to the residues of baginha $(C / N=129 / 1$ and lignin concentration $=16.0 \%)$. Marcelo et al. (2012) observed that crotalaria waste, despite having low $\mathrm{C} / \mathrm{N}$ ratio, showed low decomposition rates because of higher lignin contents. According to the work by Carvalho et al. (2009), the lignin contents to the waste of inga and baginha can be considered high (> 15\%), thus favoring the permanence of the ground coverage, by reducing the decomposition rate. Through this observation, it may be suggested that the lignin content is more determining that the $\mathrm{C} / \mathrm{N}$ ratio in the decomposition process of biomass.

As for the amount of nitrogen remaining in the waste, there was no difference $(p \geq 0.05)$ between the secondary forests or in the interaction of these with the evaluation periods (Figure 2). Initially, the waste contained 1147 $\mathrm{kg} \mathrm{ha}^{-1}$ of $\mathrm{N}$, which were reduced to $882 \mathrm{~kg} \mathrm{ha}^{-1}$, representing mineralization of $265 \mathrm{~kg} \mathrm{ha}^{-1}$ of nitrogen (23\%) in the period of 294 days after grinding (Figure 2).

In general, nitrogen fertilizer around $100 \mathrm{~kg} \mathrm{ha}^{-1}$ (Collier et al., 2006) is recommended for corn crop in no-tillage. During the 148 days of corn cultivation, in the area studies, $133 \mathrm{~kg} \mathrm{ha}^{-1} \mathrm{~N}$ were mineralized, value higher than the fertilizer recommended for the crop. However, one should consider the possibility of $\mathrm{N}$ losses by volatilization.

There was no difference $(p \geq 0.05)$ in the final stand of the corn crop, that is, the residual masses of $I$. velutina or baginha probably did not affect the germination of seeds and in the maintenance of the number of plants until the physiological maturity of seeds. However, the yield of corn grown under the inga waste was higher $(\mathrm{p}<0.05)$ than that obtained on baginha (Table 2). This result is probably due to the fact that inga residues were responsible for the greatest contribution of nutrients to the soil and had lower $(\mathrm{p}<0.05) \mathrm{C} / \mathrm{N}$ ratio than the baginha waste, providing superior results of index, diameter and length of ears, which, according to Ohland et al. (2005), are factors that determine the corn yield potential.

Another factor is that the higher amount of biomass of baginha may have implicated more intense immobilization and lower nutrient supply. According to Matias et al. (2009) in the beginning of decomposition, there is a tendency of greater immobilization of nutrients in the microbial biomass, in order to meet the nutritional needs of the microorganisms, thus resulting in a lower

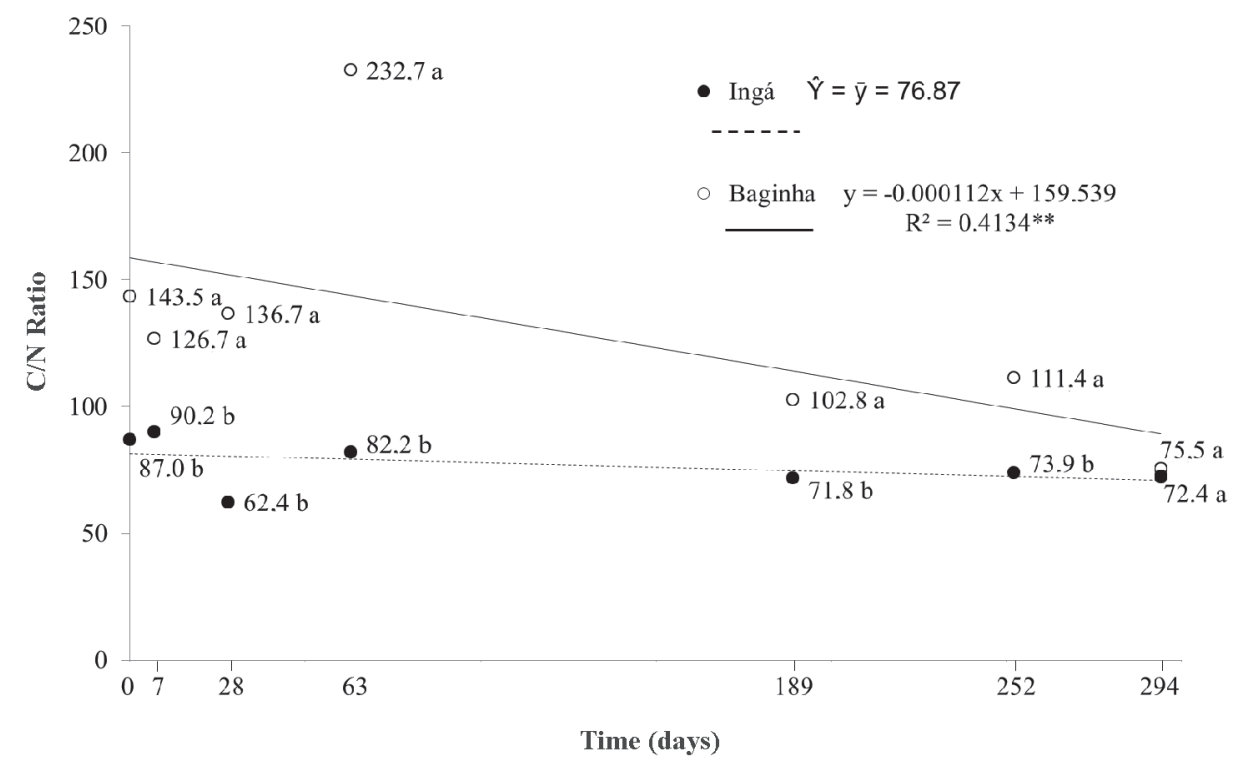

Figure 4: C/N Ratio of leguminous tree waste, after grinding the secondary forests, in Rio Branco, Acre, 2011/2012. 
availability of some elements for the crops. In addition, one should also consider the influence, in this aspect, of climate conditions and the chemical and physical characteristics of the biomass.

In terms of production of subsequent culture, an important factor is the final amount of mineralized nutrients from the ground secondary forest. However, the $\mathrm{C} / \mathrm{N}$ ratio, the lignin content, $\mathrm{k}$, and $\mathrm{t}_{1 / 2}$ can determine the magnitude of nutrient release.

In order to reduce possible damage to production by the slow release of nutrients from the organic material and their immobilization by the edaphic flora, Kato et al. (2003) recommend the use of small doses of fertilizers. In a study conducted in northeast Pará state, these authors obtained with fertilization, an average corn yield of $2600 \mathrm{~kg} \mathrm{ha}^{-1}$. Costa (2008), studying corn yield in ground secondary forest with mineral fertilizer, in Roraima state, noted an average yield of $1900 \mathrm{~kg} \mathrm{ha}^{-1}$, less than that obtained in this work, both in the area with Inga velutina $\left(3527.3 \mathrm{~kg} \mathrm{ha}^{-1}\right)$ and with baginha $\left(2150.9 \mathrm{~kg} \mathrm{ha}^{-1}\right)$. Also, it is important to point out that, even without the mineral fertilizer, corn productivity in secondary forest enriched with Inga velutina was higher $(\mathrm{p}<0.05)$ than the average productivity of Acre, $2400 \mathrm{~kg} \mathrm{ha}^{-1}$ (Agrianual, 2012) being, however, lower $(\mathrm{p}<0.05)$ than the national average of $4418.6 \mathrm{~kg} \mathrm{ha}^{-1}$ (Agrianual, 2012). Borges et al. (2011), studying enriched and natural secondary forest, in northeast Pará, found that the performance of the corn grown in areas with inga (Inga edulis) and tachi-branco (Sclerolobium paniculatum) was higher than that of corn in natural secondary forest. These results show the response of corn crop to the type of secondary forest management; and the mulch distributed on the ground is of fundamental importance in nutrient cycling.

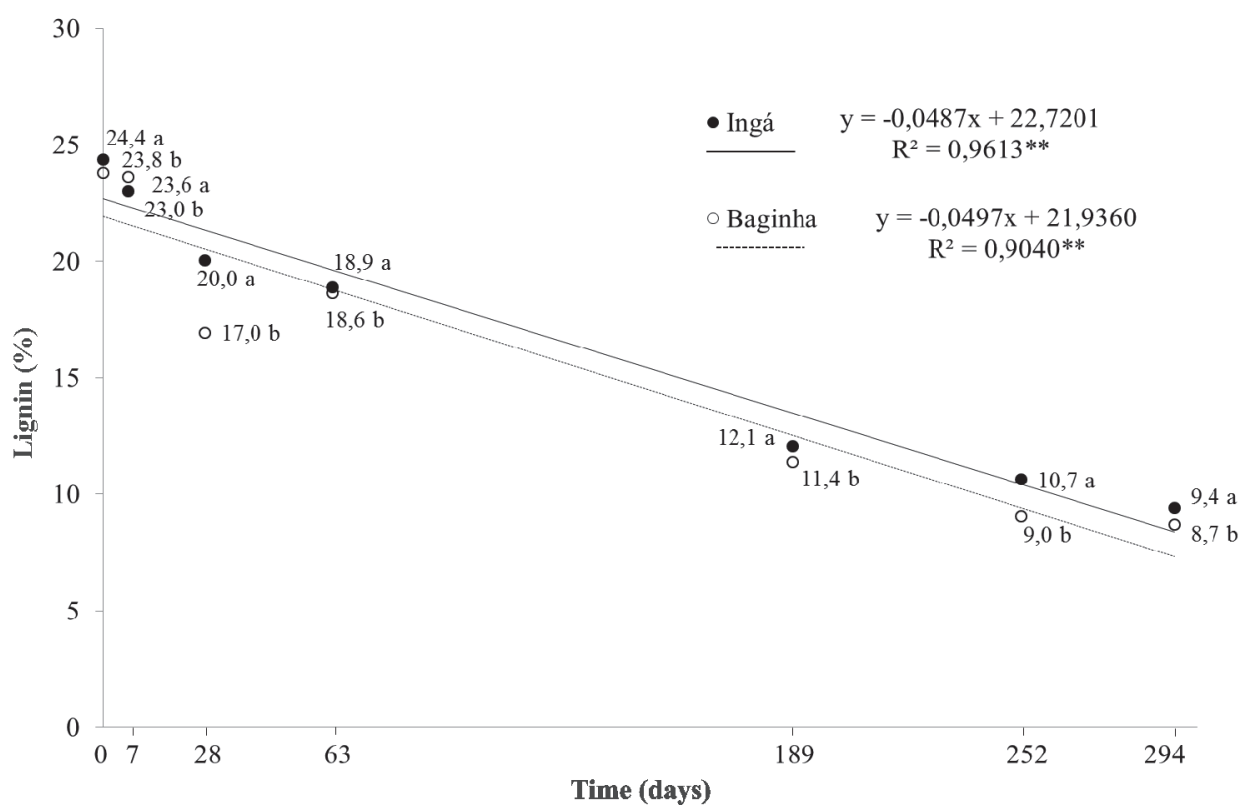

Figure 5: Lignin concentration in legume tree resideus after grinding the secondary forests, in Rio Branco, Acre, 2011/2012.

Table 2: Final Stand (FS), plant height (PH), index (EI), diameter (ED) and ear length (EL) and productivity assessed in corn crop, and final stand (FS), number of pods per plant (NPP), number of grains per pod (NGP), mass of 100 grains (M100) of the bean crop in succession to corn under no tillage on biomass of legume trees in ground secondary forest area of Rio Branco, Acre, 2011/2012

\begin{tabular}{|c|c|c|c|c|c|c|}
\hline $\begin{array}{l}\text { Secondary } \\
\text { Forests }\end{array}$ & $\begin{array}{c}\text { FS } \\
\left(\text { plant ha- } \text { ha }^{-1}\right.\end{array}$ & $\begin{array}{l}\text { PH } \\
\text { (m) }\end{array}$ & $\begin{array}{c}\text { EI } \\
\left(\text { ear plant }^{-1}\right)\end{array}$ & $\begin{array}{c}\text { ED } \\
(\mathrm{cm})\end{array}$ & $\begin{array}{c}\mathrm{EL} \\
(\mathrm{cm})\end{array}$ & $\begin{array}{l}\text { Productivity } \\
\left(\mathrm{kg} \mathrm{ha}^{-1}\right)\end{array}$ \\
\hline$\overline{\text { Ingá }}$ & $52221.70 a$ & $2.01 \mathrm{a}$ & $1.03 \mathrm{a}$ & $4.14 \mathrm{a}$ & $13.34 \mathrm{a}$ & $3527.27 \mathrm{a}$ \\
\hline Baginha & $53610.57 \mathrm{a}$ & $1.63 b$ & $0.76 b$ & $3.68 \mathrm{~b}$ & $10.54 b$ & $2150.88 b$ \\
\hline $\mathrm{CV}(\%)$ & 27.35 & 7.75 & 17.12 & 5.07 & 8.41 & 29.54 \\
\hline $\begin{array}{l}\text { Secondary } \\
\text { Forests }\end{array}$ & $\begin{array}{c}\text { FS } \\
\left(\text { plant hat }^{-1}\right)\end{array}$ & $\begin{array}{c}\text { NPP } \\
\left(\operatorname{pod}_{\text {plant }}{ }^{-1}\right)\end{array}$ & (grai & & $\begin{array}{c}\text { M100 } \\
\text { (g) }\end{array}$ & $\begin{array}{l}\text { Productivity } \\
\quad\left(\mathrm{kg} \mathrm{ha}^{-1}\right)\end{array}$ \\
\hline $\begin{array}{l}\text { Ingá } \\
\end{array}$ & $94333.33 a$ & $6.63 a$ & & & $26.08 \mathrm{a}$ & $620.81 \mathrm{a}$ \\
\hline Baginha & $105666.70 \mathrm{a}$ & $6.29 a$ & & & $26.66 \mathrm{a}$ & $609.01 \mathrm{a}$ \\
\hline$\overline{\mathrm{CV}(\%)}$ & 16.92 & 39.92 & & & 5.17 & 44.48 \\
\hline
\end{tabular}

Means followed by the same letter do not differ by $\mathrm{F}$ test at $5 \%$ probability.

Rev. Ceres, Viçosa, v. 62, n.6, p. 568-576, nov-dez, 2015 
Although Inga velutina waste contributed to the increase in corn productivity indicators, this result was not repeated in the bean crop when the Inga waste showed a similar effect $(\mathrm{p} \geq 0.05)$ to baginha in all variables, except for the number of seeds per pod (Table 2). However, the average bean productivity $\left(614.9 \mathrm{~kg} \mathrm{ha}^{-1}\right)$ was higher $(\mathrm{p}<0.05)$ than the average productivity of Acre $\left(541.0 \mathrm{~kg} \mathrm{ha}^{-1}\right)$.

Probably, the divergent results derived from the effects of waste from the secondary forest in corn and bean, is due to differences between the amount of nutrients added to the soil in both areas, from residue decomposition, besides the distinct nutritional requirements of crops.

It must be considered that corn sowing was performed five days after the grinding of secondary forest, and the bean sowing, 155 days after the grinding of secondary forest, suffering various effects of microbial immobilization processes and nutrient mineralization.

These results show the importance of improving secondary forest, associated to the knowledge of the chemical composition of the waste deposited in the soil, in order to match their maximum coverage with an adequate supply of nutrients to plants grown in it.

\section{CONCLUSIONS}

The dynamics of decomposition of secondary forest waste with Inga velutina or baginha are similar.

The productivity of corn grown in a secondary forest area with ground Inga velutina is greater than the corn grown in secondary forest with baginha.

The bean has similar productivity when grown in succession to corn in ground secondary forest areas of Inga velutina or baginha.

\section{REFERENCES}

Acre (2010) Secretaria de Estado de Meio Ambiente. Zoneamento ecológico-econômico do Estado do Acre: documento síntese, $2^{\mathrm{a}}$ fase Rio Branco, SECTMA. 354p.

Agrianual (2012) Anuário da agricultura brasileira. FNP, São Paulo. 482p.

Andrade CMS, Salman AK \& Oliveira TK (2012) Guia arbopasto: manual de identificação e seleção de espécies arbóreas para sistemas silvipastoris. Brasília, Embrapa. 345p.

Borges ACMR, Kato OR, Pinheiro HA, Shimizu MK, Rangel Vasconcelos LGT \& Oliveira Júnior MCM (2011) Crescimento e produção de fitomassa de variedades de milho em diferentes manejos da capoeira. Pesquisa Agropecuária Brasileira, 46:143-151.

Calonego JC, Gil FC, Rocco VF \& Santos EA (2012) Persistência e liberação de nutrientes da palha de milho, braquiária e labe-labe. Bioscience Journal, 28:770-781.

Carvalho AM, Bustamante MMC, Sousa Junior JGA \& Vivaldi LJ (2008) Decomposição de resíduos vegetais em Latossolo sob cultivo de milho e plantas de cobertura. Revista Brasileira de Ciência do Solo, 32:2831-2838.
Carvalho AM, Souza LLP, Alves PCAC \& Guimarães Júnior R (2009) Composição química de plantas de cobertura e decomposição de resíduos vegetais. Planaltina, Embrapa Cerrados. 15p. (Boletim de Pesquisa e Desenvolvimento, 258).

Collier LS, Castro DV, Dias Neto JJ, Brito DR \& Ribeiro PAA (2006) Manejo da adubação nitrogenada para o milho sob palhada de leguminosas em plantio direto em Gurupi, TO. Ciência Rural, 36:11001105 .

Costa MCG (2008) Calagem e adubação no primeiro ano de cultivo em sistema de corte e trituração em Roraima. Boa Vista, Embrapa Roraima. 20p. (Boletim de pesquisa e desenvolvimento, 01).

Denich M, Vlek PLG, Sá TDA, Vielhauer K \& Lücke W (2005) A concept for the development of fire-free fallow management in the Eastern Amazon, Brazil. Agriculture, Ecosystems and Environment, 110:4358.

Dick DP, Martinazzo R, Dalmalin RSD, Jacques AVA, Mielniczuk J \& Rosa AS (2008) Impacto da queima nos atributos químicos e na composição química da matéria orgânica do solo e na vegetação. Pesquisa Agropecuária Brasileira, 43:633-640.

Espindola JAA, Guerra JGM, Almeida DL, Teixeira MG \& Urquiaga S (2006) Decomposição e liberação de nutrientes acumulados em leguminosas herbáceas perenes consorciadas com bananeira. Revista Brasileira de Ciência do Solo, 30:321-328.

Ferreira DF (2008) SISVAR: Um programa para análises e ensino de estatística. Revista Symposium, 6:36-41.

Gama-Rodrigues AC, Gama-Rodrigues EF \& Brito EC (2007) Decomposição e liberação de nutrientes de resíduos culturais de plantas de cobertura em Argissolo Vermelho-Amarelo na região noroeste fluminense (RJ). Revista Brasileira de Ciência do Solo, 31:14211428 .

Kato OR, Kato MAS, Block KVA \& Jesus CC (2003) Cultivo do milho em sistema de corte e trituração da capoeira na Região Nordeste do Pará - efeito da época do preparo de área. Belém, Embrapa Amazônia Oriental. 18p. (Boletim de Pesquisa e Desenvolvimento, 19).

Kato OR, Kato MAS, Sá TODA \& Figueiredo R (2006) Plantio direto na capoeira. Ciência e Ambiente, 29:99-111.

Marcelo AV, Corá JE \& Fernandes C (2012) Sequências de culturas em sistema de semeadura direta. II - Decomposição e liberação de nutrientes na entressafra. Revista Brasileira de Ciência do Solo, 36:15681582 .

Matias MCBS, Salviano AAC, Leite LFC \& Araújo ASF (2009) Biomassa microbiana e estoques de $\mathrm{C}$ e $\mathrm{N}$ do solo em diferentes sistemas de manejo, no Cerrado do Estado do Piauí. Acta Scientiarum Agronomy, 31:517-521.

Nunes UR, Andrade Júnior VC, Silva EB, Santos NF, Costa HAO \& Ferreira CA (2006) Produção de palhada de plantas de cobertura e rendimento do feijão em plantio direto. Pesquisa Agropecuária Brasileira, 41:943-948.

Ohland RAA, Souza LCF, Hernani LC, Marchetti ME \& Gonçalves MC (2005) Culturas de cobertura do solo e adubação nitrogenada no milho em plantio direto. Ciência Agrotécnica, 29:538-544.

Rayol BP, Silva MFF \& Alvino FO (2006) Dinâmica da regeneração natural de florestas secundárias no município de Capitão Poço, Pará, Brasil. Amazônia: Ciência e Desenvolvimento, 2:93-109.

Rodrigues RC (2010) Métodos de análises bromatológicas de alimentos: métodos físicos, químicos e bromatológicos. Disponível em: <http://ainfo.cnptia.embrapa.br/digital/bitstream/item/40059/1/documento-306.pdf > . Acessado em: 10 de janeiro de 2014.

Salimon CI, Putz FE, Menezes-Filho L, Anderson A, Silveira M, Brown IF \& Oliveira LC (2011) Estimating state-wide biomass carbon stocks for a plan in Acre, Brazil. Forest Ecology Management, 263:555560. 
Sampaio CA, Kato OR \& Nascimento-e-Silva D (2008) Sistema de corte e trituração da capoeira sem queima como alternativa de uso da terra, rumo à sustentabilidade florestal no nordeste paraense. Revista de Gestão Social e Ambiental, 2:41-53.

Torres JLR, Pereira MG, Andrioli I, Polidoro JC \& Fabian AJ (2005) Decomposição e liberação de nitrogênio de resíduos culturais de plantas de cobertura em solo de Cerrado. Revista Brasileira de Ciência do Solo, 29:609-618.

Trindade EFS, Kato OR, Carvalho EJM \& Serafim ECS (2011) Disponibilidade de fósforo em solos manejados com e sem queima no nordeste paraense. Amazônia: Ciência \& Desenvolvimento, 6:7-19.
Vielhauer K \& Sá TDA (1999) Efeito do enriquecimento de capoeiras com árvores leguminosas de rápido crescimento para a produção agrícola no nordeste paraense. In: Seminário sobre Manejo da Vegetação Secundária para a Sustentabilidade da Agricultura Familiar da Amazônia Oriental, 1999, Belém. Anais, Embrapa Amazônia Oriental/ CNPq. p.27-34. 